\title{
RESTRICTIVE BUSINESS PRACTICES IN INTERNATIONAL TRADE
}

\author{
John E. Lockwood* and William C. Schmeisser, JR.†
}

\section{INTRODUCTION}

The United States, in a manner and to an extent unparalleled in its history, is asserting leadership in all fields towards the reconstruction and rehabilitation of the world. It has already sponsored the organization of the United Nations, the International Monetary Fund, the International Bank for Reconstruction and Development, the United Nations Educational, Scientific and Cultural Organization and other international agencies in such fields as agriculture and aviation. It is currently sponsoring an international conference on trade and employment, which it hopes will create an international trade organization and will adopt a common statement of policy to which the participating nations will agree. ${ }^{I}$ In anticipation of such a conference it has published certain "Proposals for Expansion of World Trade and Employment."2

* A.B., 1925, Williams College; LL.B., I928, Harvard University; member of the Bar of New York and of the District of Columbia; Secretary to Mr. Justice Holmes, U. S. Supreme Court, 1928-29; General Counsel, U. S. Office of Inter-American Affairs, 1940-44; Deputy Director, American Republics Office, Department of State, r944-45; member of the firm of Curtis, Mallet-Prevost, Colt \& Mosle, New York; contributor to legal periodicals.

† A.B., Yale University, I938; LL.B., Harvard University, 1941; member of Maryland Bar; U. S. Navy, I941-r946; Office of the Administrator of Export Control, r941; Liaison Officer for Board of Economic Warfare to Office of European Affairs, State Department, 1941-1942; currently associated with Curtis, Mallet-Prevost, Colt \& Mosle, New York City.

1 The United States Proposals for Expansion of World Trade and Employment were originally announced in connection with the public announcement of the British Loan Agreement on December 6, 1945. On December 1 3 th the United States issued invitations to fourteen nations to attend a preliminary conference, $(x)$ to draft a tentative charter of an international trade organization, and (2) to negotiate specific reductions of trade barriers. On February 18 , 1946, the Economic and Social Council of the United Nations approved a resolution calling an International Conference on Trade and Employment, and appointing a Preparatory Committee to draft an agenda and a draft Convention. It was originally planned to hold the Conference late in 1946 , but because of difficulties attendant upon the outcome of proceedings in the United States Senate for the ratification of the British Loan Agreement, there has been a delay in the time schedule.

The Secretary-General of the United Nations has announced that the Preparatory Committee would meet in London on the 15th of October, 1946. Following this conference, proposed tariff reductions will be presented to American industry for consideration, and then a conference of the fourteen nations invited to consider specific reciprocal tariff reductions will be held. Not until these preliminaries have been completed, will the Economic and Social Council call its International Conference on Trade and Employment.

The convening of these meetings is currently being delayed pending the outcome of the proceedings in the United States Senate for the ratification of the British Loan Agreement, to which the United States Proposals were annexed.

${ }^{2}$ Dep't of State, Proposals for Expansion of World Trade and Emplomment (Pub. 24i i, Commercial Policy Series 79, 1945). In this article, this document will often be referred to as "Proposals." 
In many phases of this program, the United States has faced a dual problem. On the one hand, it has sought common agreement upon emergency measures which would restore the world to a new political and economic equilibrium to replace the structure of political and economic relations destroyed by the war. On the other hand, it has sought to create international institutions and common agreement upon policies to be followed by the participating nations in the restored world. ${ }^{3}$ The problems of restoration of a world equilibrium are short term in nature but often very acute; the problems of permanent institutions and permanent policies are long term in nature and less immediate in their impact. Often there may be a real or apparent conflict between the measures necessary to obtain the short term objectives and the long term policies which can be resolved only by flexibility and compromise.

In any consideration of any feature of the United States Proposals, it is essential at all times to have in mind the immediate and acute short term considerations. These are that most of the industrial and trading nations of the world are struggling to reconstruct economic systems dislocated, and in many cases almost destroyed, by the war. Industrial plant, transportation and communication facilities, banking and credit and trade mechanisms must be restored or replaced and set to working again after a six-year interval. ${ }^{4}$

Not alone is there a problem of repairing destruction. In addition, there is a worldwide demand for industrial improvement and development, improved living standards and wider opportunities. Countries which were highly industrialized

\footnotetext{
${ }^{3}$ Assistant Secretary Clayton, The Importance of International Economic Relations to World Peace
} (April 2I, 1946) ${ }_{4}$ Dep'T of State BuLL. 677, 679:

"Our problems are of two kinds. There are immediate problems, relating principally to the tasks of making good the material ravages of war. There are longer-run problems, involving the organization of the world economy to achieve the maximum output of goods and services and the clevation of living standards. The two are by no means independent of each other. If we should bungle the job of solving the economic problems of the transition from war to peace, we shall certainly delay, and we may even lose, the opportunity to organize the world economy for enduring prosperity. In the cyes of people who lack a roof over their heads today, the construction of a substantial dwelling for use in the future will have to wait."

For example, the Bretton Woods Conference provided for a Bank to make loans to meet immediate short-term needs, and a Monetary Fund designed to lessen currency fluctuations, essentialy a long-term measure.

"Most important has been the recognition, which appeared first in the Joint Statement of Principles and has been carried over into the Bretton Woods Agreement of the special character of the transitional problems and the unsuitability of the Fund for handling them. The problems of relief, reconstruction and settlement of international indebtedness arising out of the war are specifically excluded from the range of the Fund's operations. . . . The Bank, on the other hand, could be very useful in the transition period itself and could help to create the more normal long-run conditions which are prerequisite to the successful operation of the Fund." John H. Williams, International Monetary Plans After Bretton Woods (Oct. 1944) 23 Foreign Afrairs 40.

4 "Even those European governments most cager to see their countries' forcign trade mave back toward normal were handicapped by the disorganized conditions left in the wake of the war-the destruction of productive facilities, the exhaustion of supplies, the disruption of transport and distribution channels, the serambled ownership in industry, the inadequacy of foreign-exchange assets, the internal financial confusion, and often also the unsettled status of the governmental regime itself. These conditions were not equally serious in all these countries, but, in practicaly all that had been directly involved in the war, a large measure of governmental control and even direct official intervention in foreign trade arrangements seemed unavoidable, at least for a time." Chalmers, Current Trends in Foreign-Trade Policies (Feb. 23, 1946) 22 FoREIGN COMMERCE WEEKIY 9. 
need, not only replacements, but new, more modern equipment, reflecting the great technological advance which took place during the war. Countries of less industrial development, many of which did not suffer physical injury during the war, also are asserting their demands for an opportunity to increase their industrial development. ${ }^{5}$

When the United Nations consider the United States Proposals from the point of view of negotiation and acceptance and afterwards from the point of view of performance, their approach will necessarily be one of national self-interest which, in turn, will be a compound of world politics, military security, political and economic theory, and basic economic needs. High on the list of these considerations will, and should be, the question of how far the proposed policies will facilitate, in the immediate future, reconstruction and economic development. Accordingly, a basic test of the success of the United States in this phase of its leadership will lie in the flexibility with which it adapts its proposals for long term policies to the current needs of the world. ${ }^{6}$

The Final Act of the Inter-Americas Conference on Problems of War and Peace (PanAmerican Union, 1945) pays especial attention to the problem of Industrialization and Economic Development. Resolution 50, entitled "Industrial Development," of that Conference set forth that:

"It is of mutual interest for industrialized countries and for those not yet industrialized to develop soundly-based industries in the latter;

"Industrialization is an appropriate method for raising the level of living of the American peoples, deriving maximum benefit from their natural and human resources, and enlarging their international trade;

"American economic solidarity will be stronger and more permanent by virtue of the growth of Inter-American commerce based upon such industrialization."

Resolution 5r, entitled "Economic Charter of the Americas," calls upon the participating nations to develop:

"A constructive basis for the sound economic development of the Americas through the development of natural resources; increased industrialization; improvement of transportation; modernization of agriculture; development of power facilities and public works; the encouragement of investment of private capital, managerial capacity, and technical skills; and the improvement of labor standards and working conditions, including collective bargaining, all leading to a rising level of living and increased consumption."

The Economic and Social Council of the United Nations, at its meeting in London in February, 1946, adopted a resolution calling for international conference on trade and employment. The agenda proposed embodied substantially the same language as the American "Proposals" but in addition included the following paragraph:

"4. Requests the Preparatory Committee, when considering the foregoing items, to take into account the special conditions which prevail in countries whose manufacturing industry is still in its initial stages of development, and the questions that arise in connection with commodities which are subject to special problems of adjustment in international markets." Dep'T of State BuLI., April 21, 1946, p. 648 .

Sec also Spruille Braden, Foregn Trade Reconstraction-The Americus (Nov. 18, 1945) 13 Dep'T of State. BuLx. 793.

" "Under these dire circumstances, they have no choice but to continue or to increase the control of their economies by governments. They must conserve carefully their foreign exchange, allocating its use to items for which there is the greatest need. They must carefully control both imports and exports. They must seek to make trade arrangements where barter deals can be effected without disturbing their balance of payments. ... .

"This pattern of trade restriction and trade barriers is not the result of free choice by the various nations. It is no devilish plot to shut the United States out of world trade, nor even to pursue the same sort of economic nationalism which was evident in the pre-war years. It is merely the result of compelling necessity....

"The world cannot be changed by any grand gesture. It will require time and patience and ingenuity and wisdom." Willard L. Thorp, The Necessity for Foreign Investment (Nov. 25, 1945) 13 Dep't of State Buli. 829 . 
The United States has come out of the war with vastly increased productive capacity. During the war, it has not only met the needs of its own army and its civilian economy, but it has supplied the armies of the United Nations in a productive achievement unparalleled in history. As a result, its economic strength is enormous and its bargaining position very great. At the same time, however, its enlarged productive capacity may be viewed as a threat by nations whose basic goal is to restore and improve their productive capacity. These nations must not only get back into production, but must find export markets to pay for the cost of their reconstruction and development. ${ }^{7}$

\section{The United States Proposals}

The United States Proposals reflect a United States foreign trade policy which antedates the war. That policy has been undeviating in its logic since Cordell Hull as Secretary of State inaugurated his Trade Agreements Program in $1934{ }^{8}$ It is a policy of breaking down, so far as possible, all barriers to the free flow of trade. It conceives that such a policy not only best promotes prosperity and full employment, but that it is an essential if world peace is to prevail. ${ }^{9}$

The United States Proposals provide for the creation of an international trade organization to promote expansion of production, exchange and consumption of goods, the reduction of trade barriers and elimination of discrimination; "thus contributing to an expanding world economy, to the establishment and maintenance in all countries of high levels of employment and real income, and the creation of economic conditions conducive to the maintenance of world peace."

They contain a chapter on general commercial policy to be followed by the mem-

$\tau$ "The most effective step which the United States can take against discriminatory bilateralism is the acceptance of imports on more favorable terms. Of course, even this step is far from a guarantee against discriminatory agreements. Russia might decide that such agreements are the best way to drive favorable bargains with the rest of the world, just as Germany did during the thirties. Even Britain, confronted with the difficult problem of paying for food and other raw materials might adopt a policy of discriminatory bilateralism. She has already done so to a limited extent. But although a liberal policy by the United States toward imports is not a guarantee against bilateralism, a restrictive policy by the United States would unquestionably force the development of a network of discriminatory agrecments. If we desire international trade to be open to all nations on equal terms, we must spread hope and opportunity throughout the world by accepting imports more freely than in the past." Sumner H. Slichter, Foreign Trade and Post War Stability (July 1943) 22 Foreign Appains 674, 685. See also Bidwell, Imports in the American Economy (Oct. 1945) 24 Foreign Afrairs 85.

${ }^{8}$ The initial authority to negotiate the reciprocal trade agreements was contained in the Reciprocal Tariff Act of June 12, 1934, 48 STAT. 943. The first agreement negotiated under this legislation was the Trade Agreement with Cuba, signed August 24, 1934, and effective September 3, 1934. (United States Exec. Agreement Series No. 67.)

"The sad fact is that the world is geared, right now, to continue economic warfare, using the full arsenal of weapons developed in the thirties and sharpened during the war. Neither we nor our neighbors have to learn the game; we know how to play it; we are organized to play it. The larger countries, especially the United States, Great Britain, and the Soviet Union, have mercly to tighten their hold on the regions to which they have easy access and, perhaps, to capture other areas through exclusive contracts, discriminatory arrangements, and barter deals. If this were to happen-as it casily might-the world, instead of being drawn together through economic intcreourse, would be split asunder into competing economic blocs. This is not the way to prosperity. It is not the way to peace." Wilcox, The American Trade Proposals: Progress in Rebuilding a Stable World (April 4, 1946) 14 DEp'T op State Bulx. 630. 
ber nations, which calls for reduction of tariffs and the elimination of tariff preferences, export preferences, quantitative trade restrictions, and export subsidies and exchange controls. Throughout this chapter, there are provisions-recognizing the necessity for a considerable transitional period and for the use of restrictive measures to meet emergency conditions. The chapter also recognizes that there are and will continue to be state monopolies of all foreign trade in some countries, and of individual products in others. Such monopolies are obligated to accord equal treatment to all member nations and to conduct their business on a basis of commercial considerations.

Chapter V provides for intergovernmental agreements to impose restrictions on production, exports and allocation of markets, and other restrictions which may be necessary with regard to primary commodities.

Chapter IV entitled "Restrictive Business Practices" calls for individual and concerted efforts by the members to curb those restrictive business practices in international trade (of which certain enumerated examples are given) which have the effect of frustrating the objectives of the organization. This chapter contains no exceptions with reference to any transitional period of special circumstances, or the meeting of any emergency situations.

The present article will concern itself primarily with an analysis of some of the implications of Chapter IV of the Proposals.

The Proposal with Regard to Restrictive Business Practices

As was just pointed out, Chapter IV calls for individual and concerted "efforts" by members of the proposed trade organization to "curb" restrictive business practices which frustrate the objectives of the organization. As examples of such practices, it enumerates combinations or agreements (a) to fix prices and terms of sale, (b) to divide markets or territories, (c) to limit production or exports, (d) to suppress technology or invention, (e) to exclude enterprises from particular fields, and (f) to boycott or discriminate against particular firms.

Enforcement is left to the individual members. The International Trade Organization can only receive complaints, and make reports and recommendations. There is provision for cooperation between members for the "making more effective any remedial order which has been issued by a duly authorized agency of another member." In the preliminary analysis which accompanies the Proposals, it is stated:

"In the United States enforcement would continue to be by judicial proceedings under the Antitrust Laws."

Chapter IV is very general in its terms. It covers only one printed page of text. There is no description of the administrative or judicial processes by which it would be made effective.

A recent article in the State Department Bulletin by an officer of that Department's Office of International Trade Policy, discusses this chapter of the Proposals. ${ }^{\mathbf{1 0}}$

${ }^{10}$ Terrill, The American Trade Proposals: Restrictive Business Practices (March 24, 1946) I4 DeP'T op State Bull. 455. 
This article discusses the difficulty of obtaining international agreement upon precise definitions of what restrictive business practices should be regarded as illegal. It points out that:

"Traditions, customs, legal systems and administrative proceedings, however, are too diverse among countries to entertain a sanguine hope now for this achievement in a short time. Even if this end could be accomplished, the greatest common denominator of accord among the governments might still be quite small."11

Accordingly, the author explains that this chapter of the Proposals would establish an agreement in principle among the nations that restrictive business practices should be curbed, but would establish the specified list of practices as only prima facie violations. The author states:

"The merit of this proposed agreement lies in its flexibility and its prospects for early operation."12

We may then understand that the United States Government, through this Proposal, is seeking to obtain agreement on a rather general principle, which would establish a target or goal towards which it will be the policy of this government to seek as rapid progress as possible. The goal would be substantially uniform policies, legislation, and measures to curb or eliminate restrictive business practices by each of the participating nations. ${ }^{13}$

\section{The Bastc Polrcy Should Have Fulx Support in the United States}

The basic policy of which this Proposal is an expression is widely accepted as sound by American public opinion, and has been given legislative expression by our anti-trust laws. It is a policy based upon a belief that competition between individuals and enterprises results in the production of the best product at the best price and that hence the public interest is best served. The theory has been stated in terms of its effect upon the individual and his contribution to society by Mr. Justice Brandeis in his book "Business-A Profession." Among other expressions upon this subject he stated:

"Already the displacement of the small independent business man by the huge corporation with its myriad of employees, its absentee ownership and its financier control presents a grave danger to our democracy. The social loss is great; and there is no economic gain. But the process of capitalizing free Americans is not an inevitable one. It is not even in accord with the natural law of business. It is largely the result of unwise, man-made, privilege-creating law, which has stimulated existing tendencies to inequality instead of discouraging them."14

$$
{ }^{12} \text { Id. at } 490 \text {. }{ }^{12} \text { Ibid. }
$$

${ }^{18}$ This article does not consider the question as to whether or not the United States is likely to obtain acceptance of its Proposals and specifically of Chapter IV. For purposes of this article, it will be presumed that at the projected international conference the United States Proposal on restrictive business practices will be adopted verbatim. That presumption applies to all that follows in this article.

The text of the United States Proposal does not mention the word "cartel," although this term is often applied to the subject matter. The word is used in the introduction. Since the text is, by hypothesis, the language of the agreement which will be adopted, this article does not use the word "cartel," but throughout refers to "restrictive business practices."

14 BrANDeis, Business-A Profession (1914) 223. 
The theory has been more recently stated by Judge Learned Hand as follows:

"Many people believe that possession of unchallenged economic power deadens initiative, discourages thrift and depresses energy; that immunity from competition is a narcotic and rivalry is a stimulant, to industrial progress; that the spur of constant stress is necessary to counteract an inevitable disposition to let well enough alone. Such people believe that competitors versed in the craft as no consumer can be, will be quick to detect opportunities for saving and new shifts in production, and be eager to profit by them."15

This theory is widely accepted in the United States. ${ }^{16}$ We do not apply it without exceptions, or to the limit of its logic, but it is a general guidepost for our conduct. It is the theory of liberal capitalistic democracy upon which our whole political and economic system is based. It would presumably be to the best interest of the United States that this theory should prevail throughout the world.

In so far as Chapter IV of the Proposals is an embodiment of that theory, it should have full support. We should all wish to our negotiators the fullest success in obtaining its adoption. ${ }^{17}$

But this chapter is more than a statement of a theory to which we subscribe and to which we seek adherence by others. It is a proposal for an international agreement between nations from which definite and immediate consequences will result affecting directly the citizens of those nations. Unlike the other chapters of the Proposals, this provision does not call for a relaxation of Government activity. It calls for activity against individuals or corporations to suppress or curb agreements or activities which the individual or corporation would otherwise undertake. We must therefore, direct our attention to the application of the theory.

\section{The Proposals and the United States Anti-Trust Laws}

The United States Proposals provide that each of the member nations shall obligate itself to make efforts to curb restrictive business practices. Each nation is to adopt and enforce its own statutes or decrees designed to advance the purpose. Pro-

${ }^{28}$ United Statcs v. Aluminum Co. of America, 148 F. (2d) 416, 427 (C. C. A. 2d, 1945).

10 "In the United States, government policy, widely supported by public opinion, is hostile to the participation of American firms in international cartels. The maintenance of the American system of private enterprise is grounded on the assumption that it is a competitive system and that active competition among our business firms is essential to promote technical progress and to insure an equitable division of the national income." Bidwell, A Commercial Policy for the United Namons (The Committee on International Economic Policy, 1945) 49.

${ }^{27}$ The United States Proposal with respect to restrictive business practices had its origin in a letter of September 6, 1944, from President Roosevelt to Secretary of State Hull which set forth that:

"During the past half century the United States has developed a tradition in opposition to private monopolies. ... This policy goes hand in glove with the liberal principles of international trade for which you have stood through many years of public service. . . Unfortunately a number of foreign countries, particularly in continental Europe, do not possess such a tradition against cartels. ... I hope that you will keep your eye on this whole subject of international cartels because we are approaching the time when discussions will almost certainly arise between us and other nations." (Sept. 10, r944) 12 Dep't of State BuLI. 254.

To this letter Secretary Hull replied on September II, I944:

"I shall continue to follow closely the progress of this work on the subject of international cartels, ... in the near future, and consistent with the pressing demands of the war upon your time, I want to present to you in more detail plans for discussion with other United Nations in respect to the whole subject of commercial policy." (Sept. 17, 1944) 12 Dep't of Stste Bul. 292. 
vision is made for cooperation between members to make more effective any remedial action which may have been taken by a member. The International Organization itself is not authorized to take enforcement measures.

Thus the measures to curb restrictive practices are to be taken by the different nations acting individually. The International Organization is assigned only a coordinating role. The Proposals provide for an international policy but not for international enforcement.

In its analysis of the Proposals, the United States Government announces that "in the United States, enforcement would continue to be by judicial proceedings under the anti-trust laws." No adequate appraisal of Chapter IV of the United States Proposals can therefore be made which fails to take into consideration the current policies, legislation, and procedures of the United States Government with respect to enforcement of the anti-trust laws. This is the case not only because the United States has said that it will continue to enforce those laws as it has in the past, but also because of the implication that other nations may be expected to adopt similar laws and procedures.

No administrative machinery is provided for the interpretation of our anti-trust laws. Individuals and business enterprises are called upon to conduct their affairs at the peril that, if they misinterpret the meaning of the general legislative language, they will be subjected to punitive action. Enforcement takes the form of criminal or civil proceedings presented by the Department of Justice before our courts.

These criminal or civil proceedings may be brought long after the events took place which are the subject of the proceedings. ${ }^{18}$ They may be initiated at a time when enforcement policies and judicial interpretations of the general language of the statutes have altered radically from those which prevailed when the acts complained of took place.

The proceedings may result in a judgment for the defendant, but often only after weeks of trial, thousands of pages of testimony and exhibits, and protracted appeals involving enormous expense and interruption of the services of key defendants or their officers. ${ }^{19}$ Often such proceedings terminate through negotiations re-

\footnotetext{
${ }^{18}$ For example, in the Aluminum case, supra note 15 , the transaction involved could be said to have commenced in $x 889$ when the patent on the manufacture of pure aluminum was obtained, or perhaps better in 1909 when the ultimate patent expired. As Judge Hand stated in that case: "The most important question in the case is whether the monopoly in 'Alcoa's' production of 'virgin' ingot secured by the two patents until 1909 and in part perpetuated between 1902 and 1912 by the unlawful practices, forbidden by the decree of 1912, continued for the ensuing 28 years." Supra note 15, at 422-423.

In the Hartford-Empire case the transaction extended over a period beginning about 1904 and until the time of the trial. Hartford Empire Co. v. United States, 323 U. S. 386 (1945).

${ }^{10}$ In the Aluminum case the bill of complaint was filed in April, 1937, the action went to trial in June, 1938, and the trial lasted without much interruption until August, 1940. When the case was closed more than 40,000 pages of testimony had been taken. The trial judge delivered an oral opinion from September 30 to October 9, 194I, and supported it with 407 findings of fact. Stupra note 15, at 42x. The final decree in this case was entered on April 23, 1946, just nine years to the day from the filing of the complaint. In the Hartford-Empire case the trial lasted I12 days. The court filed an opinion of 160 pages, 628 findings of fact, and 89 conclusions of law, and entered a decree covering 46 printed pages and comprising 60 numbered paragraphs. The printed record contained over 16,500 pages. 323 U. S. at 392.
} 
sulting in a consent decree which enjoins the defendant against various types of conduct into the infinite future.

A decision for the government may result in criminal penalties or a similar decree, or both. Such decrees are normally broad in scope and often contain "report clauses" calling upon the defendant to file with the Department of Justice any future restrictive agreements of a specified type. ${ }^{20}$

The United States anti-trust laws are primarily a matter of our domestic policy. But they also, by their terms, apply to our foreign commerce. In its earliest interpretation of their application to foreign commerce, the United States Supreme Court gave a limited interpretation of their extraterritorial affect. In American Banana Co. v: United Fruit Co., ${ }^{202}$ which involved an action for triple damages under the Sherman Act by reason of acts which had taken place entirely outside the United States and principally in Costa Rica, including acts of the Costa Rican Government, the court refused to apply the Sherman Act even though United States own citizens were involved, because the acts involved were performd abroad. In that case, in reaching this decision, the court said:

"But the general and almost universal rule is that the character of an act as lawful or unlawful must be determined wholly by the law of the country where the act is done. Slater v. Mexican National R. R. Co., I94 U. S. 120 , 126. This principle was carried to an extreme in Milliken v. Pratt, I25 Massachusetts, 374. For another jurisdiction, if it should happen to lay hold of the actor, to treat him according to its own notions rather than those of the place where he did the acts, not only would be unjust, but would be an interference with the authority of another sovereign, contrary to the comity of nations, which the other state concerned justly might resent. Phillips v. Eyre, L. R. 4 Q. B. 225, 239; L. R. 6 Q. B. I, 28; Dicey, Conflict of Laws (2d ed.), 647. See also Appendix, 724, 726, Note 2, ibid."

But there are later numerous decisions indicating that the anti-trust laws will be applied if any single step in a chain of action occurs in this country, or if acts abroad cause effect here and jurisdiction can be had over the parties. ${ }^{21}$

If United States commerce is affected, enforcement action may be taken against foreign citizens or foreign corporations. ${ }^{22}$ Such action has been initiated with respect to transactions within the jurisdiction of a foreign government, both as to the

${ }^{30}$ A discussion of such report clauses can be found in Oseas, Anti-trust Prosecution of International Business (1944) 30 CoRN. L. Q. 42, 60.

${ }^{20 \pi} 213$ U. S. 347 (1909).

${ }^{31}$ United States v. Pacific and Arctic Railway Co., 228 U. S. 87 (19I7); United States v. Sisal Sales Corp., 274 U. S. 268 (rg27).

${ }^{22}$ United States v. Nord Deutscher Lloyd, 223 U. S. 5 I2 (1912); United States v. Hamburg American Line, 239 U. S. 466 . Currently pending are DeBeers Consolidated Mines v. United States, 325 U. S. 212 (1945), in which the defendants were three corporations organized under the laws of South Africa, corporations organized under the laws of the Belgian Congo, under the laws of Portugal, of Belgium and of the United Kingdom, together with a number of individuals. In that case, in view of the diffculty of obtaining personal jurisdiction over the parties, an attempt was made to obtain an injunction which would, in effect, freeze their bank accounts in the United States. The court held that the injunctive relief should be denied and reversed the decree of the court below granting it. The decision was five to four. 
place of the making of the agreement and as to the place of its performance. ${ }^{23}$ The transactions may be entirely valid under the laws of the foreign government or even approved by that government. Neither approval by the foreign government of the transaction nor its participation therein will prevent the United States from initiating enforcement measures under its anti-trust laws. ${ }^{24}$

The question of determining when United States commerce is affected presents problems of great difficulty. As Judge Learned Hand pointed out in the Aluminum case:

"Almost any limitation of the supply of goods in Europe, for example, or in South America may have repercussions in the United States if there is trade between the two."20

In that case, the court analyzed at some length the tests as to when a transaction affected foreign commerce sufficiently for the purposes of the anti-trust laws. It discussed the importance of intent as related to performance. For purposes of the case, it assumed that intention to affect that commerce was not enough unless the performance should be shown actually to have had some effect upon it. It also held, however, that if an intent to affect our imports or exports was proved, the burden of proof shifted to the defendant to show that the intent was not carried out in actual results.

For present purposes, it is not necessary to analyze the precise limits of this juris-

${ }^{23}$ In the DeBeers Consolidated Mines case, stupra note 22, the counsel for the United States submitted an affidavit which stated that "The investigation which he has made shows the foreign corporate defendants named herein have endeavored to avoid subjecting themselves to the jurisdiction of the courts of the United States by making their sales abroad only and requiring customers to pay in advance for all purchases."

${ }^{34}$ Wendell Berge, Assistant Attorney General of the United States, states:

"Our courts may control foreign citizens or corporations operating wholly in foreign territory, where their operations extend into the domestic and foreign commerce of this country. . . . It is recognized that some cartel arrangements are instigated by or under cover of foreign governmental authority, but unless the cartel arrangements complained of are solely participated in by the forcign government, the situation is not altered.

"While a foreign sovereign may have immunity from suit, such immunity does not apply to private individuals or organizations even though they may be acting pursuant to the laws of their own country, or though a foreign government may have a substantial financial interest in the challenged organization and activities." Berge, Cartels: Challenge to a Free World (1944).

See also the substantially similar statement by KREPs, A CanTEL PoLicr for trae UnITed Nations (1945) $84-85$. The precise application of the policy above stated to particular situations is not entircly clear. There may be a number of different variations of the situation referred to. For cxample, (a) the forcign nation may have no legislation on the subject of restrictive practices; (b) the law may be as in (a) but the foreign government may have given more or less formal indication of its desircs that certain restrictive practices should be followed, or of its approval of them; (c) the law may be as in (a) but the government may, through loans or through partial ownership, have a participation in management through which it causes the restrictive action; (d) the law may provide for regulation of restrictive practices, but the particular kind may either not be forbidden or be expressly permitted; (c) the law may provide for administrative regulation of restrictive practices and the particular practice may have been approved; (f) the law may require that certain restrictive practices be engaged in. The authors interpret the above quotation as indicating the belief of the chief enforcement officer for our anti-trust laws that in every one of those cases the defendant would be subject to proceedings under our anti-trust laws if our commerce could be shown to be affected. The only defense which would be recognized is sovereign immunity. In this connection, see Clayton, Private Barriers to International Trade (May 20, I945) I3 Dep'r of State Bull. 933, 937.

${ }_{25}$ United States v. Aluminum Co. of America, supra note 15, at 443. 
diction. The substance of the matter is that the United States anti-trust laws, as now interpreted, apply to acts abroad and may be enforced where jurisdiction over the parties may be obtained here.

The Proposal throws no light on the subject of jurisdiction. By its terms it calls for action by each nation to curb restrictive business practices "in international trade." Presumably, any nation, including the United States, could adopt legislation applying its enforcement measures to any restrictive practices "in international trade," regardless of whether the trade of that particular nation was affected. It could be urged that such action was taken in support of the international obligation. There has been no hint given as to whether the United States would seek so to amend its own anti-trust laws as to confer upon it this broadened jurisdiction or whether we would merely continue to enforce those laws as they stand. It would seem reasonable to assume, however, that the Department of Justice, in the event of the adoption of the Proposal, would seek to implement it with enforcement as vigorous and as broad in scope as the law and Congressional appropriations would authorize. It is currently pressing for broad interpretations of the extraterritorial effect of the anti-trust laws. Vigorous enforcement in cases of foreign trade could be pointed to as support by the United States of its obligations and would conform to policies expressed by those responsible for anti-trust enforcement in this country. ${ }^{26}$

${ }^{20}$ See BERGE and Clayton, supra note 24. An indication of the purpose of the Department of Justice to seek the widest possible extraterritorial application of the anti-trust laws may be found in the recently terminated proceeding to settle the decree against Aluminum Ltd., one of the parties to the United States v. Aluminum Co. of America. In connection with the settlement of that decree, Aluminum Ltd. proposed the inclusion of a clause restricting the application of the decree territorially. The form of the clause was substantially the same as similar clauses which had been included in the decrees settling United States v. Allied Chemical and Dye Company, CCH Trade Reg. Serv. 194I-43, 152, 606, X, and United States v. Imperial Chemical Industries (NY) Ltd., CCH Trade Reg. Serv, 194I-43, 152, 79I, VIII. The Department of Justice opposed the inclusion in the decree of such a clause limiting its extraterritorial effect. The court, in entering judgment, included a clause for territorial limitation reading as follows:

"This judgment shall have no effect with respect to operations or activities outside the U. S., its territories and the District of Columbia not violative of the Anti-Trust Laws in force at the time of such opcrations or activitics. Nor shall this judgment have any effect with respect to operations and activities within the U. S., its territories and the District of Columbia relating exclusively to acts and operations outside the U. S., its territories, and the District of Columbia not violative of the Anti-Trust Laws in force at the time of such operations or activities."

In addition, in the settlement of this decree, the Department of Justice requested the inclusion of a report clause reading as follows:

"That Aluminum Limited, its officers and directors, and their successors, transferees, and assignees be and they hereby are ordered to file with this court and to serve upon the Atty.-Gen., thirty days prior to the execution thereof, a copy of any agreement to which Aluminum Ltd., its successors, transferees, or assignees may become a party, directly or indirectly, through subsidiaries, affiliates, agents, or otherwise, and any modification or amendment thereto, which limits or restricts competition in the production or sale of aluminum or products fabricated therefrom in any market of the world outside of the United States, including, but not limited to any agreement which limits production, fixes prices, allocates customers, fixes sales quotas, or otherwise restricts sales or which provides for a continuing exchange of patents or technological information." (Italics supplied.)

The court, in entering the decree, did not include such a provision.

As is pointed out in Oseas, supra note 20, at 6I: "The special report clause is apparently still in the 
In the light of the foregoing, we may summarize the United States Proposal as seeking international agreement to a generalized statement of policy directed to the curbing of restrictive business practices. The undertaking is to be given effect by the United States, through the enforcement of its own laws by criminal or civil proceedings instituted with respect to any persons regardless of nationality, and with respect to any transactions regardless of situs, provided (a) that United States commerce is affected or possibly (b) wherever international trade is affected.

The United States policy of enforcing extraterritorially its anti-trust laws is a purely nationalistic policy whose wisdom may be doubted. It represents a determination on the part of this country to make its anti-trust policy effective, so far as possible, all over the world, regardless of the policies of other nations. The statement in the United States Analysis of its Proposals that it will continue to enforce the anti-trust laws may be regarded as a warning to all other nations that it will continue to seek to do just this.

It is difficult to see how such a policy can be suggested as a basis for international agreement. If the United States can seek to enforce its policy extraterritorially, surely every other nation can do the same. The result would seem inevitably to be conflicts between national policies whose immediate impact would fall upon those endeavoring to carry on international trade.

\section{The Proposals Must Be Flexible Enough to Allow for Diversity}

\section{in Basic Approach}

The Proposal calls for very general agreement between the nations to curb those restrictive business practices in international trade which have the effect of frustrating the objectives of the Organization to promote expansion of production and trade, equal access to markets and raw materials, and the maintenance in all countries of high levels of employment and real income. It then leaves it up to each nation by its own laws and procedures to determine what are the prohibited restrictive practices and to punish them.

Such a plan for unilateral application of a general principle might result in a workable degree of uniformity and mutual understanding and cooperation if the subject matter were relatively simple and if there were among the nations substantial agreement on the fundamentals. It could then be presumed that on any given state of facts they would reach substantially the same result. Accordingly, in any case in which the United States would be taking enforcement measures with respect

process of being worked out, and ... is being progressively improved. The form used in the Aluminum Company decrees (a decree earlier than that above referred to) may indicate an attempt to achicve a system of filing cartel information."

The proposal of the Department of Justice to omit a territorial limitation clause and to include a world-wide report clause, is evidence that efforts will be made to project abroad to the furthest limit possible the application of our anti-trust laws. 
to transactions in another country, it could be presumed that the law of that country would also prohibit such transactions. But neither the prohibition contained in the United States Proposal, nor the language of our own Sherman Act (which prohibits contracts or combinations in restraint of trade) has such simplicity and definiteness as to lead to such a result.

Our own experience with the Sherman Act clearly demonstrates the complexity of the problem. It takes months of trial, thousands of pages of testimony and exhibits, and a long series of court decisions to determine whether one particular set of transactions violates our law. We have been administering the Sherman Act for half a century and yet the body of judicial decisions which has evolved during that half century does not furnish any simple set of rules. With the exception of contracts fixing prices-and probably those which divide a territory among producerswhich are generally held to be unlawful whatever the circumstances, each case, under our law, is determined on its own particular facts. A "rule of reason" is applied.

In Appalachian Coals, Inc. v. United States, ${ }^{27}$ the Supreme Court upheld as valid a domestic combination in the coal industry which frankly eliminated competition among the members of the group to enable it to deal with the organized buying power of large purchasers. Coal producers created a common selling agency, which was made the exclusive agent of each to sell the coal, to apportion orders and to fix prices. The court upheld the validity of this combination on the ground that it was justifiable in order to avoid destructive competition and eliminate unfair practices. The court stated that elimination of competition among the members was not necessarily unlawful. In referring to the "rule of reason," the court stated:

"In applying this test, a close and objective scrutiny of particular conditions and purposes is necessary in each case. Realities must dominate the judgment. The mere fact that the parties to an agreement eliminate competition between themselves is not enough to condemn it." (Italics added.) ${ }^{28}$

In appraising the effect of the combination, the court noted:

". . A cooperative enterprise, otherwise free from objection, which carries with it no monopolistic menace, is not to be condemned as an undue restraint merely because it may effect a change in market conditions, where the change would be in mitigation of recognized evils and would not impair, but rather foster, fair competitive opportunities. Voluntary action to rescue and preserve these opportunities, and thus to aid in relieving a depressed industry and in reviving commerce by placing competition upon a sounder basis, may be more efficacious than an attempt to provide remedies through legal processes. The fact that the correction of abuses may tend to stabilize a business, or to produce fairer price levels, does not mean that the abuses should go uncorrected or that cooperative endeavor to correct them necessarily constitutes an unreasonable restraint of trade. The intelligent conduct of commerce through the acquisition of full information of all relevant facts may properly be sought by the cooperation of those engaged in trade, although stabilization of trade and more reasonable prices may be the result. Maple Flooring Association v. United States, supra; Cement Manufacturers Association v. United States, 268

${ }_{27} 288$ U. S. 344 (r933).

${ }^{28}$ Id. at 360 . 
U. S. 588, 604. Putting an end to injurious practices and the consequent improvement of the competitive position of a group of producers, is not a less worthy aim and may be entirely consonant with the public interest, where the group must still meet effective com. petition in a fair market and neither seeks nor is able to effect a domination of prices." (Italics added.) $^{29}$

Later decisions have limited the holding in the Appalachian case to its precise facts. ${ }^{30}$ But, whatever its application to other situations, the importance of the case is that it demonstrates that the test under the anti-trust laws is, in the last analysis, one of reasonableness and that the decision must be made in the light of all the pertinent conditions.

Moreover, we in the United States have not always been logically consistent, but have legislated a vast number of exceptions to the Sherman Act. Large sections of our economy are exempted from the anti-trust laws and subjected instead to administrative regulation. ${ }^{31}$ Historically our own industries have developed by protective tariffs. Within recent months, we have been seeking to impose quotas on the imports of Swiss watches.

There is an attempt in the Proposal to give a degree of certainty by the enumeration of a series of prima facie violations. It may be questioned whether such a list should be written into the basic document. We have never written any such list into our own law, despite numerous efforts throughout its history to clarify its meaning. It might well be better for the International Conference to limit its conclusions to the adoption of broad policies, leaving questions of their detailed application to the Permanent International Trade Organization.

This proposed list of prima facie violations is founded in the experience of the United States under the anti-trust laws and could furnish a starting point for the

29 Id. at $373-374$.

${ }^{30}$ The court, in deciding the Appalachian case, stipra note 27 , relied more on the fact that the combination controlled too little of the supply to affect the price of coal than that price fixing may be justified by a need to correct evils. This was indicated by the court in distinguishing the Trenton Potteries case ( 288 U. S. at p. 375 ) and the limits of the decision were clearly pointed out in United States v. SoconyVacuum Oil Co., 3 Io U. S. 150 (1940) at p. 214 et seq. And see United States v. Aluminum Company of America, supra note 15 , at 427 .

"1 Interstate Commerce Act (1887) and Transportation Act of x920, 24 STAT. 379 as amended, 49 U. S. C. $\$ \mathrm{x}$, et seq.; Shipping Act of $19 \mathrm{r} 6,39$ STAT. 728 as amended, 46 U. S. C. $\$ 801$, et seq.; Packers and Stockyards Act (1921) as amended, 42 STAT. 159, 7 U. S. C. 5181 , et seq.; Capper-Volstead Act of 1922, 42 STAT. 388, 7 U. S. C. $\$ \$ 291,292$; Perishable Agricultural Commodities Act (1930) as amended, 46 Strit. 53I, 7 U. S. C. $\$ 499 \mathrm{a}-499 \mathrm{r}$; Labor Provisions-Clayton Act (1914), 38 STAT. 730, 73I as amended, 15 U. S. C. $\$ \$ 12,17$ and Norris-LaGuardia Anti-Injunction Act (1932) 47 STAT. 70, 29 U. S. C. \$\$10x-115; Agricultural Adjustment Act of 1933, 48 Stat. 31 as amended and reenacted by the Agricultural Marketing Agreements Act of 1937,7 U. S. C. \$601 et seq.; National Industrial Recovery Act (1933), 48 Stat. I95 as amended in 48 STAT. II 83 and 49 Stat. 375, 15 U. S. C. S701 et seq.; Communications Act of 1934, 48 STAT. 1064, 47 U. S. C. $\$ 15 I$ et seq.; Fisheries Cooperative Marketing Act (1934), 48 STAT. 1213, 15 U. S. C. \$52I et seq.; Conally Hot Oil Act (1935), 49 StAT. 30 as amended, 15 U. S. C. \$7I5 et seq.; Poultry Amendment to Packers and Stockyards Act (1935), 49 Stat. 648, 7 U. S. C. \$218; Interstate Oil Compact Act (1943), 57 StAT. 383; State Tobacco Compacts Act (1936), 49 STAT. 1239, 7 U. S. C. $\$ \$ 515-515 \mathrm{~K}$; Motor Carriers Act of 1935, 49 STAT. 543 as amended, I5 U. S. C. $\$ 77 \mathrm{C}$ and 49 U. S. C. \$30r et seq.; Bituminous Coal Act (1937), 50 Srar. 72 as amended, 15 U. S. C. $\$ 828$ et seq.; Civil Aeronautics Act (1938), 52 STAT. 977, 49 U. S. C. $\$ \$ 488,489$, 492; Small Business Mobilization Act (1942), 56 STAT. 351, 12 U. S. C. $\$ \$ 84,265$, 15 U. S. C. $\$ 606$ b: 50 U. S. C. App. (Supp. 1943) §1 ior et seq. 
work of the permanent organization..$^{32}$ However, we must recognize that there has been and continues to be a controversy as to whether restrictive practices are presumptively bad or whether there is not a distinction between those practices which are good and those which are not. ${ }^{33}$ Support of restrictive practices has been strongest on the continent of Europe.

There are many who believe that controls lead to stability and order. Particularly is this the case where there are surpluses which might result in heavy losses and unemployment or shortages threatening serious hardships or inflationary pressures. Emphasis is also placed upon the fact that today the cost of capital investment in many industries is so great that some protection from the hazards of the market is necessary if the risk of making the investment is to be undertaken. Dangers of rapid obsolescence or of killing competition from established companies desirous of destroying a new competitor are emphasized. Smaller or less developed nations often consider restrictions upon free competition as the only protection against the economic power of larger and more highly developed industrial nations. The uncertainties which exist in the world today are so great as to give such arguments particular point.

Therefore, an attempt to write what is basically legislation into a document in the nature of a constitution presents risks both of raising avoidable controversies at the Conference and of imposing upon the permanent organization rules which it might better work out on the basis of its own studies. Any enforcement program which is to be applied separately by many nations must be one which has the flexibility necessary to encompass much diversity.

\section{The Application of the Proposals Must Be Flexible Enough for the IMMEdiate Economic Necessities}

The United States Proposal is designed to alter radically the rules governing the commercial and industrial organization of the world. It is based upon principles which heretofore have had acceptance primarily in the United States. Most nations of the world have subscribed to no such theory of the validity of unlimited competition and the invalidity of combinations and agreements between businessmen. ${ }^{34}$ Even Great Britain whose legal tradition is the same as ours places a very different and much narrower interpretation upon the phrase "restraint of trade." There is in the

${ }^{32}$ Judicial decisions appear to have established pretty definitely that contracts fixing prices [United States v. Trenton Potteries Company, 273 U. S. 392 (1927); United States v. Socony-Vacuum Company, 3 Io U. S. I50 (x940)]—and probably those which divide a territory among producers [United States v. Addystone Pipe \& Steel Co., 85 Fed. 27x (C. C. A. 6th, 1898); and see United States v. Aluminum Company, supra note 15 , at 427]-are unlawful regardless of the circumstances. But, as a general proposition under our law, each case is determined on its own particular facts. A "rule of reason" is applied. Standard Oil Co. v. United States, 22 I U. S. I (I9II); American Tobacco Company v. United States, 22 I U. S. I06 (I9II); Appalachian Coals, Inc. v. United States, 288 U. S. 344 (I933).

${ }^{33}$ See the analytical discussion of this whole subject and references to different opinions in HEXNER, Internationai Cartels (1945) 45-56.

s' T. N. E. C., Monograph No. 40 (Regulation of Economic Activities in Foreign Countries, r94r). In Canada, however, a government report has recommended policies substantially similar to those proposed by the United States. Canada and Internationnal Cartels (Report of Commissioner, Combines Investigation Act, Ottawa, 1945). 
world outside the United States no accepted tradition, practice, or body of judicial decisions to mark the course which other nations would be expected to follow. ${ }^{35}$ It should be presumed accordingly, that genuine efforts by different nations to accept the policy and apply it, would produce widely divergent results.

This would be the case even if all the nations of the world accepted the underlying premises upon which the United States policy is based. They are the premises of liberal capitalistic democracy. But much of the world does not accept these principles; many nations accept them only to a limited degree. The economy of a vastly important area of the world is based upon the theory of communism, whose premises are entirely different. The economics of certain other nations are based to greater or less degree upon the premises of socialism. We cannot expect a reasonable degree of uniformity of interpretation and enforcement where the very premises upon which our theory is based are not accepted in large areas of the world.

Many nations of the world, faced with the necessity to revive and develop their industrial production under great difficulties, must manage important sectors of their economies. Internally, they must see to it that capital funds, technical skills, labor and production are first directed to the restoration of industry and communications and the building up of capital goods, thus delaying for the present the satisfaction of consumer needs. Externally, they must acquire foreign exchange by borrowing, by attracting capital for investment and by exports, and they must conserve their foreign exchange against its dissipation in the purchase of luxuries or other articles or services not needed at the present time. These are the absolute and primary necessities in greater or less degree of a large number of nations of the world. ${ }^{36}$

We cannot expect other nations in this situation to apply our principle of curbing restrictive business practices immediately and without the adjustments which they may deem necessary for their national purposes. They can achieve their purposes either by programs of socialization of production and state monopolies of trade, or they can achieve them through the regulation of the activities of private industry. A program of enforcement such as we have announced, by which we may bring criminal proceedings against private individuals and corporations who may be conforming to restrictive and managed programs in other countries, can, at the least, hamper the reconstruction and development of those countries. It could force a greater and greater degree of socialization and state trading.

Of equal, perhaps greater, importance is the effect of such an enforcement policy upon the flow abroad of new American private capital. Such investment abroad in

3r T. N. E. C., Monograph No. 40, stipra note 34 .

30 "Each government feels that its immediate responsibility for its country's economic rehabilitation includes planning for its essential import requirements, and direct supervision over the utilization of the limited amounts of foreign supplies, shipping, and exchange that are available to insure that the most vital needs of the nation are given priority. This attitude seems general, even in those Europcan countries whose long-term plans do not contemplate government control of particular industrics or sectors of the domestic economy." Chalmers. supra note 4 . 
I940 was estimated by the Department of Commerce at $\$ 7,000,000,000 .^{37}$ Today the United States has more than an adequate amount of funds seeking investment outlets. To the other countries of the world, a flow of such funds would mean that they could obtain much needed machinery and technical skills without the necessity to draw upon their limited supply of dollars. Such private American investment could assume large proportions and supplement the loans of this Government and the loans which will be made by the International Bank for Reconstruction and Development. Whether or not such investment money flows freely from this country to the other nations of the world, may well determine whether the economy and trade of the world can be restored and developed through private channels. ${ }^{38}$

For such investments to be made, the investor must see a reasonable degree of scurity for his capital and a return of income. He must look ahead a number of years and calculate his risks against his opportunities for profit. The risks which face such capital investments today in many parts of the world are very great. They are risks attendant upon the political instability which exists and the absence of an economic equilibrium. Although the flow of such investment may be an essential to world recovery and to the future of our economic system, any investor must hesitate in the face of the risks which confront him.

There is a tide of opinion abroad which insists that foreign capital shall become more closely identified with the nation in which it is invested than once was the case. The participation of local investors in the enterprise, the employment of local personnel and technicians so far as possible, and, above all, domestication and submission to local laws and policies, is urged and often insisted upon.

Such policies increase the hazard for the potential investor. But such risks are being taken, and there are many who urge that the investment pattern of the future must emphasize this kind of adaptation by the foreign capitalist to the policies of the country in which he would conduct his business.

Such adaptation would be rendered much more difficult if our laws at home threaten prosecution for acts taken in conformity with the local law. This would present an element of risk for which no compensatory adjustments could be made. By this treatment of private enterprise we place another risk in the way of private investment, and, by so doing, threaten the success of our Proposals as a whole.

\section{Conclusions and ReCommendations}

As a general statement of Trade Policy, Chapter IV of the Proposals for Expansion of World Trade and Employment is an appropriate expression of the United States position. This position is based upon its history. and long held beliefs. Leaving aside the enumeration of specific prima facie violations, the language in which the proposed commitment is expressed is well conceived. It is not too rigid. The nations are only asked to use "efforts" to "curb" restrictive business practices. There

st U. S. Dep't of Comm., Americhn Direct Investment in Foreign Countries-ig40.

${ }^{88}$ See Thorp, loc. cit. supra note 6. 
is no absolute prohibition. There is room here for each nation to adapt its application of the principle to its own needs.

So also, only those restrictive business practices are to be curbed as "frustrate the purposes of the Organization." Here again there is ample flexibility and room for interpretation. Any nation can read into this language its own traditions, philosophy and needs.

On the whole, the statement of the principle is satisfactory, and it may be hoped that it will be adopted. It is when we come to the application of the broad principle that difficulties arise.

To support the logical implications of our Proposal, we should have authorized the International Trade Organization to act as an international administrative agency with authority to write the rules and regulations and to make decisions in specific cases. In such case, the Proposals would have called upon the member nations to apply the rules and enforce the decisions of this administrative agency. The rules and decisions of this agency would represent a consensus of international opinion and be based upon consideration of all aspects of each problem. Uniformity in the interpretation and application of the common principle would result.

But, as in the case of enforcement measures by the United Nations itself, we have not felt that the world was prepared to take such bold measures. Hence our Proposal is a compromise which leaves to the individual nations, acting separately, the basic task of application of the principle. It is admitted that this is bound to result in a period of lack of uniformity. But it is inherent in our continued reliance upon separate national sovereignties as basic and independent units. Probably the United States Proposal goes as far towards an international solution as is reasonably practical at the moment.

Since, then, there is to be unilateral enforcement, the danger is that different nations, interpreting and enforcing the agreement differently, will be at cross purposes; some may attempt to enforce policies regardless of the considerations which lead other nations to adopt different ones. It presents to those who carry on the trade and commerce of the world the risk that they may be subject to liability in one country for action which is approved in another.

Should we not recognize this danger, and meet it by seeking to obtain at the coming Trade Conference international agreement defining the jurisdiction of the various nations to approve and disapprove of transactions and to take enforcement measures with respect to them? This of course, would not be an easy task. The law of the conflict of laws of different nations varies in accordance with the differences in their systems of law. Traditionally our law has accentuated the law of the place of the transaction as the determinant. ${ }^{39}$

so "Two conceptions as to the Nature of Law have divided the modern world. (I) That law is the personal right of someone whose law it is; the native of some country or the domiciliary of some place whose law is to extend to the protection of the person wherever he goes. (2) That the law is territorial, that there can be no law in a particular state except the law of that state, and therefore that a foreigner coming into that state can by no means bring with him his personal law even for his own 
Agreement on jurisdiction seems vital and should be a part of the agreement on policy. An agreement on jurisdictional limitations to be incorporated by each member nation into its domestic law and to be interpreted and applied by the courts of the respective nations, would seem to be the most logical solution.

Such an agreement should stipulate that, if, by the law of the proper nation, as so determined, a transaction is held to be valid or invalid, that decision will be accepted by all of the member nations. It should further be agreed that enforcement proceedings could be taken by any country with regard to an agreement invalid by the law of the proper country, but only if the enforcing country's trade is directly affected.

Even if agreement on jurisdictional limits should be difficult to obtain, it would seem essential that the problem should be fully discussed. Debate should help to explain differing points of view and lead to the mutual understanding which is essential if unilateral enforcement of a common policy is to succeed.

Such a jurisdictional agreement would involve on the part of the United States a willingness to accept a limitation upon the extraterritorial enforcement of its antitrust laws. It would mean acceptance of the proposition that one nation might apply the basic principle, upon which all have agreed, differently from the way another would. One nation might approve transactions which another thought undesirable or disapprove those which another thought sound. Producing nations might approve a restrictive arrangement which would affect another's imports or fix their price. This is inherent in the retention under our Proposal of full sovereignty in the participating nations. In such event, an aggrieved nation should try either directly or through the Organization to persuade the nation whose standards are deficient to change its ways. Such a procedure of international persuasion seems infinitely preferable to extraterritorial enforcement by each nation of its own laws.

The adoption of such a rule limiting and defining the jurisdiction of each nation with respect to restrictive business practices would remove most of the dangers inherent in the United States Proposal as it now stands. It would respect the sovereignty of each nation and permit each to make decisions in accordance with its own needs and traditions. It would require acceptance of these decisions by other nations subject to their right to persuade a change. It would reduce the danger of conflicting policies applied through conflicting enforcement measures against individuals. It would avoid the risk of pressure by one nation seeking to impose its philosophies on another. It would permit business and trade to be carried on with reasonable certainty as to which rules governed its conduct. It should contribute measurably to world revival and industrial development.

protection; the foreigner coming in is subject to the law of the state as much as the nationals of the state. The conception of the common law has always been the conception of a territorial law. No law is administered as such by the courts except the territorial law. In some European countries the conception is otherwise, and it is believed that the law personal to a human being may accompany him and compete for control with the territorial law of the place where he acts." BEale, Conflict of LAws (x935) 52 . 
In addition, as a matter of our domestic policy here in the United States, consideration should be given to the question whether the problem of passing upon the validity of the complex interrelationships of international trade and industrial organization should not be vested in a more flexible instrument than is furnished by the anti-trust laws. There are many strong arguments for dealing with these problems through an administrative agency authorized to consider transactions in advance and to give rulings with respect to them and to issue rules, regulations and decisions of general application as well as to take enforcement measures. ${ }^{40}$

Such an agency would be able to work with the International Trade Organization. It should have broader discretion and be able to take into consideration a far wider range of pertinent factors than an agency charged by law with seeing only that a statute primarily of domestic application is obeyed according to its terms. It would set a better pattern for world cooperation than a reliance upon judicial proceedings which, inevitably, must fall within a rigid pattern. The decisions of such an agency would furnish to businessmen a degree of certainty as to where they stand, which is their very reasonable need. It should encourage the taking of business risks which otherwise would seem too great. It would enable other nations and their nationals to know, more clearly than they can today, just where they stand when they deal with us. Trade flourishes best in an atmosphere of predictability and continuity. It is as important to such an atmosphere that the rules of the game be clear as it is to have exchange rates stable.

There are contrary considerations. The very complexity of the problem might place upon such an agency a load of responsibility almost impossible to discharge. Foreign trade is a simple conception but, in practice, it is a compound of myriads of transactions and relationships. Much of it is carried on by small enterprises which are specialists in their fields. It comprises all the world and almost all its products. Administrative regulation of this field might well find itself snowed under by the mass of detail and the variety of judgments to be made. The subject deserves careful study. ${ }^{41}$

What is vital is that there should be full recognition of the complexity of the task of applying the principle we propose to the business of the world in which we live. Our principle is a long-term principle based on theories which we consider important but which are not fully accepted elsewhere in the world at the present time. To make them effective is a problem of persuading other nations of the validity and worth of the standards we support, not of the efficiency and vigor of the extraterritorial enforcement measures to be taken by a domestic agency. Such enforcement would be the antithesis of collaborative effort between nations holding mutual respect for the laws of others and endeavoring by international agreement to conciliate their differences.

\footnotetext{
¿0 National Foretgn Trade Council, Inc., Memorandum on Regulatory Measures Affectino Aarerican Foreign Trane (r944).

"Included in such study might well be a consideration of the present trends in the Antitrust Division of the Department of Justice. Is it, today, a mere enforcement agency, or is it, in fact, extercising a rather wide degree of discretion?
} 
The success of all of our foreign policies, political as well as economic, will be dependent upon whether or not the practical needs of a war-torn world are met. Today, the over-riding consideration is that people must be fed, homes and factories rebuilt, industry and trade revived, jobs must be plentiful and real wages rise. Many kinds of restrictions will be resorted to to speed this process. As we pursue our goal of world-wide free competition, we must be flexible enough to accept these restrictions; we must recognize that other nations will have their own ways of meeting their specialized problems. Only when these urgent needs have been met, and only with the passage of time and by the force of our example and persuasion can we hope to achieve our goal. 